\title{
Spatiotemporal patterns of latrine-site use by small-clawed otters in a heterogeneous rice field landscape
}

\author{
Aadrean $^{1,2, *}$ and Nisikawa Usio ${ }^{1,3}$ \\ ${ }^{1}$ Graduate School of Natural Science and Technology, Kanazawa University, Kanazawa 920-1192, Japan \\ ${ }^{2}$ Biology Department, Andalas University, Padang West Sumatra 25163, Indonesia \\ ${ }^{3}$ Institute of Nature and Environmental Technology, Kanazawa University, Kanazawa 920-1192, Japan
}

\begin{abstract}
Tropical rice fields with asynchronous growth stages provide a good model to investigate the effects of landscape heterogeneity on the use of agricultural landscapes by wildlife. The smallclawed otter (Aonyx cinereus) uses rice fields as latrine sites in Southeast Asia. Through a 53-week survey of latrine sites, we analyzed the spatiotemporal patterns of latrine-site use by small-clawed otters in an asynchronous rice field in West Sumatra, Indonesia. Based on a generalized linear mixed model incorporating local environmental factors, otter latrine-site visitation was positively associated with the vegetative stage of rice cultivation and the biomass of a major prey item, the golden apple snail (Pomacea canaliculata). The vegetative stage of rice cultivation and golden apple snail biomass were closely associated with deep water in rice fields; therefore, water availability in rice fields is likely important in determining the spatiotemporal patterns of small-clawed otter latrine-site use in the asynchronous rice field landscape. To consistently provide latrine sites for small-clawed otters, we recommend that asynchronous rice cultivation be maintained, or zoning of synchronous and asynchronous rice cultivation areas be planned in the region.
\end{abstract}

Key words: asynchronous cultivation, generalized linear mixed model, prey availability, water availability.

Landscape heterogeneity is a contemporary issue in biodiversity conservation and integrated pest management in agricultural ecosystems (Zhao et al. 2016; Collins and Fahrig 2017; Monck-Whipp et al. 2018). Fahrig et al. (2011) defined two types of landscape heterogeneity; configurational heterogeneity denotes various sizes or spatial arrangements of a specific landscape component, whereas compositional heterogeneity refers to various types of land use (e.g., farmland, treed stands, settlements, etc.). Thus, landscapes containing complex spatial patterns or various patch sizes exhibit configurational heterogeneity and landscapes with various land uses exhibit compositional heterogeneity. Although rice fields are typically characterized by low landscape heterogeneity, tropical rice fields with asynchronous planting cycles can comprise both configurational and compositional heterogeneity. Asynchronous rice cultivation divides the landscape into differently-sized patches of rice fields with differential rice growing stages, and these patches of various growing stages can be considered as different land-use components.

Rice field landscapes are characterized by dramatic changes in vegetation structure and water conditions according to farmland management or cropping activities. In cool temperate regions, rice field management and rice planting cycles are primarily determined by seasonality or associated changes in climatic factors (Usio 2014). In such regions, the richness and abundance of wildlife, such as wetland birds, have been shown to be high during the summer irrigation season (Amano et al. 2008). However, in some tropical regions with little seasonal climatic variations, farming activities are largely unaffected by seasonality. In such regions, various growth stages can be found at any time of year. Therefore, tropical rice fields provide a good model to investigate the effects of heterogeneous growth stages or farmland management on wildlife use of agricultural landscapes.

*Towhom correspondence should be addressed.E-mail: aadrean@sci.unand.ac.id 
Otters are among the top predators in wetland habitats. Among four otter species in Asia, the small-clawed otter (Aonyx cinereus) occurs in South and Southeast Asia (Kruuk 2006). Although small-clawed otters typically inhabit relatively pristine wetland habitats (Kruuk et al. 1994; Perinchery et al. 2011; Raha and Hussain 2016), they are also known to use human-altered wetland habitats such as rice fields (Foster-Turley 1992; Aadrean et al. 2010; Gonzalez 2010; Kanchanasaka and Duplaix 2011). Small-clawed otters are known to consume a variety of prey items including fish, crabs, snails, insects, frogs, reptiles, and small mammals (Kruuk et al. 1994; Abdul-Patah et al. 2014).

For otters, latrine sites play an important role in communication among family members or small social groups (Hutchings and White 2000). Numerous studies have documented the spatial patterns of otter latrine sites (Kruuk 1992; Barocas et al. 2016). Food availability and water body type are key factors that explain the number of scats deposited at latrine sites of the river otter, Lontra canadensis (Crowley et al. 2012). Temporal use of otter latrine sites has also attracted much attention in northern temperate or subarctic regions; in river otters in North America, latrine-site activity is highest in spring (MarchApril) and fall (September-November) (Olson et al. 2008; Stevens and Serfass 2008), whereas the activity of Eurasian otters (Lutra lutra) in the United Kingdom is highest in winter and lowest in summer (Macdonald and Mason 1987; Kruuk 1992). Nevertheless, effects of landscape heterogeneity on the spatiotemporal patterns of otter latrine-site use remain to be tested.

We previously demonstrated that spatial patterns of small-clawed otter latrine-site use were related to local and landscape factors specific to rice field landscapes, such as the number of rice field huts, distance from a settlement, and the yearly mean water depth of an adjacent rice field (Aadrean and Usio 2017). In this study, we tested whether the spatiotemporal use of small-clawed otter latrine sites was associated with the growing stages or farmland management of rice cultivation by incorporating temporal changes of environmental factors in an asynchronous rice field landscape. Because rice fields undergo dramatic changes in water and food availability for small-clawed otters over time, we hypothesized that spatiotemporal patterns of otter latrine-site use were associated with specific growing stages of rice cultivation. From these results, we propose management implications for Indonesian rice fields with special reference to latrinesite use of small-clawed otters.

\section{Methods}

\section{Study site}

The study site was located in a rice field along the Batang Anai River in Padang Pariaman Regency, West Sumatra, Indonesia. Padang Pariaman Regency has a tropical climate, and is warm (monthly average temperature range: $22.7-27.3^{\circ} \mathrm{C}$ ) and humid (monthly average humidity range: $82.3-91.2 \%$ ) throughout the year with little seasonal variation. November is the wettest month and June is the driest month, although the monthly average humidity generally exceeds $80 \%$, with 12 days of precipitation per month, even in June (Badan Pusat Statistik-Statistics of Padang Pariaman Regency, https:// padangpariamankab.bps.go.id/, Accessed 30 August 2017).

The Anai Dam and its associated irrigation system were constructed in 1996 to provide a consistent supply of irrigated water to 13640 ha of farmland along the middle to lower reaches of the Batang Anai River. Rice fields are irrigated with dam water throughout the year in these areas. Because climate does not seriously affect the timing of rice planting, farmers can grow rice two to three times a year at their discretion. Consequently, rice can be found at all growing stages at any time, i.e., plantation cycles are asynchronous.

Major agricultural pests in the study site include rats (Rattus spp.), planthoppers (Nilaparvata lugens and Sogatella furcifera), golden apple snails (Pomacea canaliculata), and birds (Estrildidae and Ploceidae). To effectively control agricultural pests, the Indonesian government promotes synchronous rice cultivation. At present, most farmers do not follow government recommendations because of a lack of information, motivation, or cooperation, as well as insufficient communication between farmers and the government due to limitations in financial or human resources.

\section{Field surveys}

Preliminary field surveys were performed in 2008 and 2010 to identify the latrine sites of small-clawed otters in a rice field landscape in the Batang Anai River drainage basin (Aadrean et al. 2010). Latrine sites were first located by walking along main ditches and levees along upper and lower areas of irrigated rice fields, while looking for otter footprints in the rice fields that may have led to latrine sites. Additional information on latrine sites was gained from farmers encountered during these preliminary field surveys. Consequently, 27 latrine sites were identified along the Batang Anai River drainage basin, 


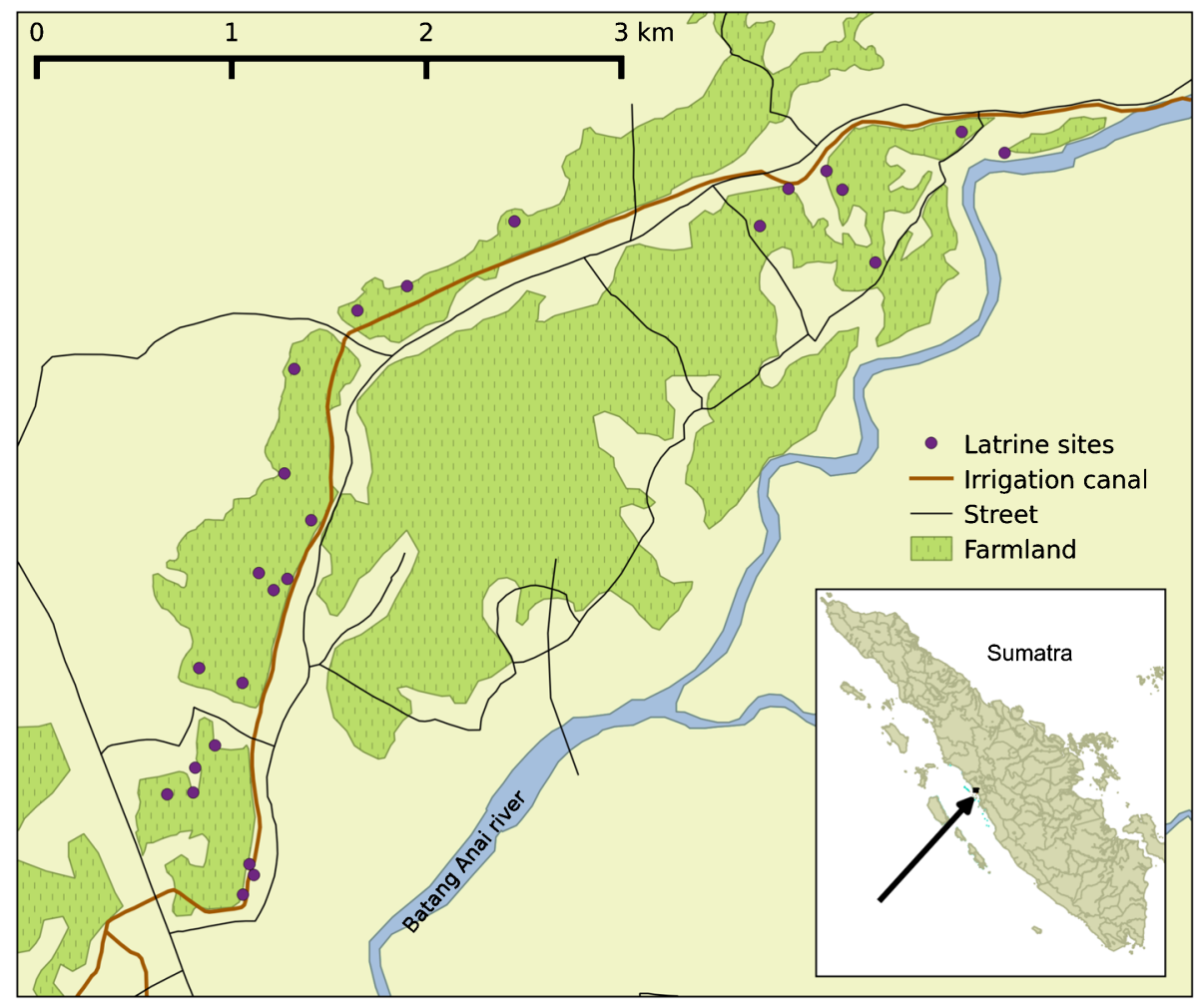

Fig. 1. Study area map showing the locations of 25 latrine sites in cultivated rice fields in the upper Batang Anai River drainage basin, West Sumatra, Indonesia.

with 19 sites in the upper area and eight sites in the lower area (Fig. 1). Many areas in the lower Batang Anai River drainage are highly degraded by conversion to dry farmland, such as corn fields or palm oil plantations; thus, we only monitored otter latrine sites that were located in the upper drainage area, which encompasses 648 ha of rice fields (Fig. 1). Because the areas of three latrine sites had been converted into roads or shrubland between 2010 and 2015, we monitored 16 of the 19 previously encountered latrine sites for further analysis. From February to April 2015, we performed a survey in the upper area of the Batang Anai River drainage basin to locate additional latrine sites and located nine new sites. In this study, we used 16 sites that were first located in 2008 or 2010 and nine sites located in 2015, for a total of 25 latrine sites (Aadrean and Usio 2017).

We monitored the 25 sites weekly over 53 weeks from April 12, 2015, to April 10, 2016. On each occasion, we recorded the presence of new spraints (otter scats). To assure that the spraints were new, we collected and removed old spraints during each survey. We also recorded water depth and the biomass of golden apple snails (a major food item of small-clawed otters; Aadrean et al. 2011) in the adjacent rice field as measures of local environmental conditions. Using a ruler, we measured the water depth (to the nearest $1 \mathrm{~cm}$ ) at one location of the rice field nearest the latrine site. If the bottom of the rice field was uneven, we measured the depth at several points along the levee to calculate mean water depth. Golden apple snails were collected from a plot $(20 \mathrm{~cm} \times$ $200 \mathrm{~cm}$ ) that was delineated by first placing a 2-m rope along the levee and subsequently placing $20-\mathrm{cm}$ sticks perpendicular to the levee near the latrine site. The wet biomass of golden apple snails was determined (to the nearest $0.1 \mathrm{~g}$ ) using a digital scale.

In addition, we categorized the growing stages of rice plants into the following four stages: post-harvest, preparation, vegetative, and reproductive [modified from International Rice Research Institute (2007)]. The post-harvest stage refers to the period between harvest and plowing. The preparation stage is defined as the period between plowing and rice transplantation. The vegetative stage reflects the period between transplantation and flowering of rice plants and the reproductive stage reflects the period between flowering and harvesting. According to the International Rice Research Institute (2007), panicle initiation is considered as the start of the reproductive stage. Because panicle initiation could not be judged 
easily from a distance, we used flowering as the signal of the end of the vegetative stage and start of the subsequent reproductive stage. We considered a rice field to be in the reproductive stage when at least one flower was observed in the rice field. Furthermore, we combined the ripening (matured rice grain) and reproductive stages within the reproductive stage.

\section{Data analysis}

Both water depth and snail biomass data displayed a strongly right-skewed distribution, and thus were squareroot transformed prior to analyses (Zuur et al. 2010). We used the generalized variance inflation factor (GVIF) to examine multicollinearity among variables (Fox and Monette 1992). The GVIF value allows an evaluation of multicollinearity involving categorical variables. For continuous variables, GVIF is the same as VIF. In general, GVIF > 10 indicates high multicollinearity, while GVIF $=1$ indicates that the predictor is not correlated with other predictors. We used a conservative threshold of GVIF $>3$ as an indication of multicollinearity (Zuur et al. 2009). For categorical variables, GVIF has degrees of freedom $(d f)$ equal to the number of levels (categories) -1 . Thus, we used GVIF corrected by degrees of freedom $\left(\mathrm{GVIF}^{1 / 2 d f}\right)$ to make the GVIF values comparable among variables with different $d f$. When assessing multicollinearity with the $\mathrm{GVIF}^{1 / 2 d f}$ value, we used an equivalent threshold of $>1.73$ (equal to $\sqrt{3}$ ).

Using a generalized linear mixed effect model (GLMM) with a binomial distribution (logit link), we modeled the occurrence of small-clawed otter spraints in each weekly survey as the response and three local environmental variables (rice growing stage, water depth, and golden apple snail biomass), and their interaction terms, as predictors. We considered spraints to represent one otter occurrence regardless of the size and number of spraints. In GLMMs, we treated latrine sites within weeks as a random factor and three local environmental variables and interaction terms as fixed factors.

We examined all variable combinations, including interactions among variables, resulting in 12 candidate models. We used Akaike's Information Criterion correction for small samples (AICc) to select the best supported model. When more than one model met the threshold of $\triangle \mathrm{AICc}<2$, we selected the most parsimonious model (i.e., containing the fewest number of parameters). We assessed model performance using conditional $R^{2}$, the equivalent of $R^{2}$ in least-square models (Nakagawa and Schielzeth 2013).
We conducted all statistical analyses using $\mathrm{R}$ (R Core Team 2018). We used the 'corvif' function to calculate GVIF (Zuur et al. 2009), the package 'Ime4' to perform GLMM analyses (Bates et al. 2015), and the package 'MuMIn' to calculate AICc values and conditional $R^{2}$ values (Bartoń 2016).

\section{Results}

At least three of the four rice growing stages were encountered (mean $\pm S D=3.77 \pm 0.43$ ) during each weekly survey. We detected signs of small-clawed otter activity at latrine sites in 297 of 1325 observations. The mean $( \pm S D$ ) water depth was $1.67 \mathrm{~cm} \pm 2.69$ (range 0-30 $\mathrm{cm})$, while the mean $( \pm S D)$ snail biomass was $8.13 \mathrm{~g} \pm$ 22.05 (range $0-281.7 \mathrm{~g}$ ) at all latrine sites across weeks (Fig. 2).

One-way analysis of variance (ANOVA) indicated that the mean biomass of golden apple snails differed among the four growing stages $(P<0.001)$ and was highest in the vegetative stage, as determined by a post-hoc Tukey's HSD test. Likewise, mean water depth differed among the four growing stages (one-way ANOVA, $P<0.001$ ), and was deeper in the preparation and vegetative stages (post-hoc Tukey's HSD test). The GVIF ${ }^{1 / 2 d f}$ values of all three predictors were $<1.73$ (equivalent to GVIF $<3$ ) (Table 1), therefore multicollinearity was not considered to be problematic for GLMM analyses.

Twelve candidate GLMM models were evaluated (Table 2). Among these, the smallest AICc values were obtained in a model including rice growth stage and mean golden apple snail biomass (AICc $=1142.05)$, and one including rice growing stage, mean golden apple snail biomass, and mean water depth $(\mathrm{AICc}=1142.22)$. The AICc values of these models did not differ substantially, but the former model was more parsimonious than the latter. Overall, the visitation of small-clawed otters at latrine sites was significantly associated with the vegetative stage and mean golden apple snail biomass in rice fields $(P<0.01)$ (Table 3 and Fig. 2). The conditional $R^{2}$ of the best supported model was 0.41 .

\section{Discussion}

Latrine-site use was associated with a specific growing stage in fields cultivated for rice. The probabilities of otter visitations to latrine sites were high in sites adjacent to rice fields in the vegetative stage and with high golden apple snail biomass. Because rice fields in the vegetative 

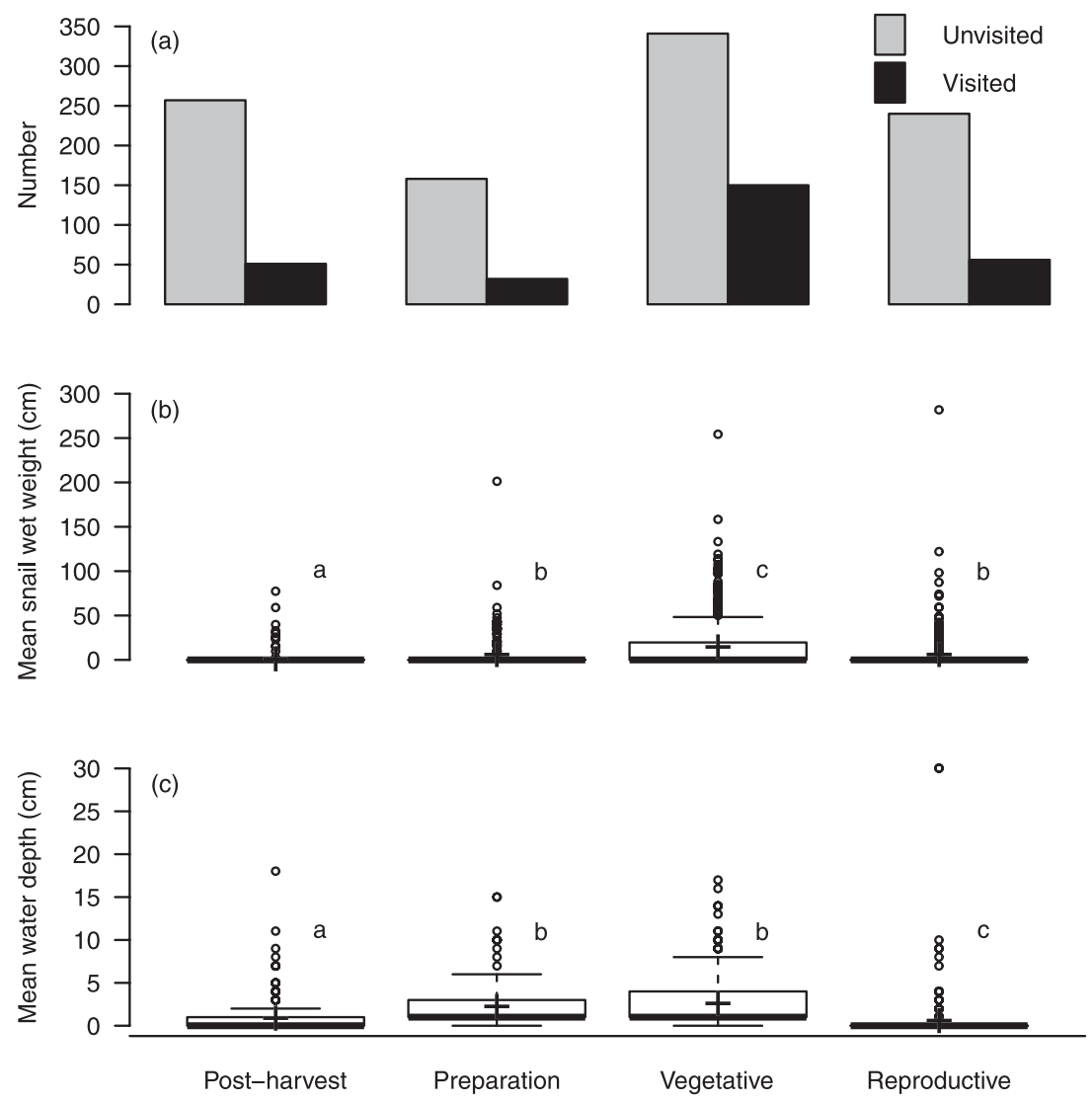

Fig. 2. Environmental variables at small-clawed otter latrine sites in rice fields of the Batang Anai River drainage basin, West Sumatra, Indonesia over a 53-week period. a) The number of unvisited (Unvisited) and visited (Visited) latrine sites according to the four rice growing stages; b) Mean golden apple snail wet biomass of rice fields adjacent to otter latrine sites; c) Mean water depth of rice fields adjacent to small-clawed otter latrine sites. See the main text (Field surveys in Methods section) for the classification of rice growing stages. All graphs are depicted using the raw data. In (b) and (c), letters indicate significant differences ( $\alpha=0.05$; ANOVA with post-hoc Tukey's HSD test).

stage tended to be associated with high golden apple snail biomass and deep water (Fig. $2 b$ and c), rice fields with abundant prey or water are presumably important in determining the spatiotemporal patterns of small-clawed otter latrine-site use. Our results are consistent with studies on the Eurasian otter in Mediterranean areas showing that habitat use is primarily influenced by water and prey availability (Prenda et al. 2001; Ruiz-Olmo et al. 2007; Almeida et al. 2012). For example, during a drought period, Eurasian otters tended to use streams and ponds containing water (Prenda et al. 2001; Ruiz-Olmo et al. 2007). Furthermore, the latrine sites of Eurasian otters were associated with river tributaries, characterized by abundant fish prey (Squalius alburnoides, Cyprinidae) during spring and summer (Almeida et al. 2012).

Although water availability and the abundance of golden apple snail prey are likely the most important factors explaining latrine-site visitations by small-clawed
Table 1. Variance inflation factors of three predictors used in generalized linear mixed-effect models explaining the visitation of small-clawed otters to latrine sites in rice fields of the upper Batang Anai River drainage basin

\begin{tabular}{lccc}
\hline Variable & GVIF & $d f$ & GVIF $^{1 / 2 d f}$ \\
\hline Stage & 1.4064 & 3 & 1.0585 \\
WaterSqrt & 1.5385 & 1 & 1.2404 \\
SnailSqrt & 1.3164 & 1 & 1.1474 \\
\hline
\end{tabular}

The variables water depth and snail biomass were square-root transformed (Sqrt). GVIF = generalized variance inflation factors; $d f=$ degree of freedom; GVIF ${ }^{1 / 2 d f}=$ GVIF corrected by degree of freedom for interpretation across parameters.

otters, water availability alone was not sufficient in explaining otter visitation. Rice fields in the preparation stage were associated with deep water in our study area, but otter visitation was infrequent, likely because golden apple snails were not abundant. Aside from food availa- 
Table 2. Summary of the results of the generalized linear mixed-effect model (GLMM) selection in explaining the visitation of small-clawed otters to latrine sites in rice fields of the upper Batang Anai River drainage basin, West Sumatra, Indonesia

\begin{tabular}{|c|c|c|c|}
\hline Formula & $\mathrm{AICc}$ & Weight & $\triangle \mathrm{AICc}$ \\
\hline Visitation $\sim$ Stage $+\sqrt{ }$ Snail $+(1 \mid$ LS/Week $)$ & 1142.05 & 0.45 & $\mathbf{0}$ \\
\hline Visitation $\sim$ Stage $+\sqrt{ }$ Water $+\sqrt{ }$ Snail $+(1 \mid$ LS/Week $)$ & 1142.22 & 0.41 & 0.17 \\
\hline Visitation $\sim$ Stage $+\sqrt{ }$ Snail + Stage $\times \sqrt{ }$ Snail $+(1 \mid$ LS $/$ Week $)$ & 1144.39 & 0.14 & 2.34 \\
\hline Visitation $\sim$ Stage $+(1 \mid$ LS/Week $)$ & 1151.81 & 0 & 9.76 \\
\hline Visitation $\sim$ Stage $+\sqrt{ }$ Water $+(1 \mid$ LS/Week $)$ & 1153.83 & 0 & 11.78 \\
\hline Visitation $\sim$ Stage $+\sqrt{ }$ Water $+\sqrt{ }$ Snail + Stage $\times \sqrt{ }$ Water $\times \sqrt{ }$ Snail $+(1 \mid$ LS $/$ Week $)$ & 1155.41 & 0 & 13.36 \\
\hline Visitation $\sim \sqrt{ }$ Snail $+(1 \mid$ LS/Week $)$ & 1156.64 & 0 & 14.59 \\
\hline Visitation $\sim \sqrt{ }$ Water $+\sqrt{ }$ Snail $+\sqrt{ }$ Water $\times \sqrt{ }$ Snail $+(1 \mid$ LS $/$ Week $)$ & 1157.80 & 0 & 15.75 \\
\hline Visitation $\sim \sqrt{ }$ Water $+\sqrt{ }$ Snail $+(1 \mid$ LS $/$ Week $)$ & 1158.49 & 0 & 16.44 \\
\hline Visitation $\sim$ Stage $+\sqrt{ }$ Water + Stage $\times \sqrt{ }$ Water $+(1 \mid$ LS/Week $)$ & 1159.04 & 0 & 16.99 \\
\hline Visitation $\sim \sqrt{ }$ Water $+(1 \mid$ LS/Week $)$ & 1182.58 & 0 & 40.53 \\
\hline Visitation $\sim 1+(1 \mid \mathrm{LS} /$ Week $)$ & 1184.91 & 0 & 42.86 \\
\hline
\end{tabular}

In GLMMs, latrine sites within weeks (1|LS/Week) was treated as a random factor, while rice growing stage (Stage), water depth (Water), and golden apple snail biomass (Snail) were treated as fixed factors to model small-clawed otter visitation to latrine sites (Visitation), where $\times$ indicates an interaction term between predictors. The data for water depth and snail biomass were square-root transformed $(\sqrt{ })$. Bold-faced font indicates the best supported model based on Akaike's Information Criterion correction for small samples (AICc) and model parsimony.

Table 3. Parameter estimates of the best supported model explaining the spatiotemporal patterns of latrine-site use of small-clawed otters in the upper Batang Anai River drainage basin

\begin{tabular}{lcr}
\hline Parameter & Estimate & \multicolumn{1}{c}{$P$} \\
\hline Intercept & -2.32980 & $<0.0001$ \\
StagePreparation & 0.06882 & 0.8029 \\
StageVegetative & $\mathbf{0 . 8 5 4 7 1}$ & $<\mathbf{0 . 0 0 0 1}$ \\
StageReproductive & 0.28591 & 0.2286 \\
$\sqrt{\text { Snail }}$ & $\mathbf{0 . 1 0 4 6 8}$ & $\mathbf{0 . 0 0 0 6}$ \\
\hline
\end{tabular}

Statistically significant variables are indicated in bold font $(P<0.05)$. StagePreparation $=$ growing stage period between plowing and rice transplantation; StageVegetative = growing stage period between transplantation and flowering of rice plants; StageReproductive $=$ growing stage period between flowering and harvesting. The variable 'Snail' (golden apple snail biomass) was square-root transformed $(\sqrt{ })$.

bility, latrine-site visitation by small-clawed otters may also be affected by the presence of rice plants. Previous research has reported that small-clawed otters rub their bodies on live rice plants in the vicinity of latrine sites (Aadrean et al. 2010). Aside from getting rid of parasites, this may be a means of communication through scentmarking among individuals or social groups (Kruuk 2006). Therefore, an absence of rice plants, and hence an absence of scent-marking substrates in the preparation stage of rice fields, may also have negative effects on latrine-site visitation by small-clawed otters.

A limitation of our study was our focus on golden- apple snails as a sole measure of prey availability. In natural wetlands, major prey items of small-clawed otters include fish, crabs, insects, and snails (Abdul-Patah et al. 2014). Although crabs rarely appeared in smallclawed otter spraints in our study area, fish and insects were frequently observed in spraints (Aadrean, unpublished data). However, methods for evaluating fish and insect prey abundance are highly dependent on the life-history characteristics of the prey taxa and, in the case of insects, whether the taxa have primarily aquatic or terrestrial life stages. Nevertheless, details of major fish and insect prey taxa remain unknown. Future studies may benefit from analyzing the composition of fish and insect prey in small-clawed otter spraints using a molecular method such as a DNA barcoding approach (Hong et al. 2019). Mobile aquatic organisms, such as some fish species, are expected to move freely within and between rice fields and adjacent diches or canals. Therefore, determining the availability of such mobile prey may be better quantified using a multi spatial-scale approach (Usio et al. 2017).

Within our study area, most stages of rice cultivation are found throughout the year. This is likely advantageous for small-clawed otters inhabiting this area, because a landscape structure comprising high water availability, prey availability, and rice plants suitable for body rubbing can be found throughout the year-round. If rice cultivation was homogenous (i.e., synchronous farming), as it 
is in cool temperate regions, microhabitat or food availability could become limited during the reproductive and post-harvest stages. In farmland, the maintenance of landscape heterogeneity is a key factor for supporting high biodiversity (Benton et al. 2003). As noted by Vasseur et al. (2013), variations in both spatial and temporal organization of agriculture practices are essential for creating or maintaining landscape heterogeneity in agricultural landscapes. Spatial and temporal variability in a rice field landscape can be created by growing the same crop at different times of year or by growing different types of crops. To maintain compositional heterogeneity across the rice field landscape, asynchronous rice cultivation should be continuously promoted in the study area.

However, the continuation of asynchronous planting cycles in the face of global warming may result in increased outbreaks of agricultural pests, such as planthoppers, which are vectors of rice tungro bacilliform virus (Holt and Chancellor 1997) or rats (Sudarmaji et al. 2010), because this practice provides consistent food and habitat for pest species (Settle et al. 1996). Therefore, a key challenge in farmland conservation is to balance the trade-off between wildlife conservation and agricultural pest management. If synchronous rice farming is to be promoted in Indonesian rice fields, zoning may be required, in which synchronous and asynchronous rice cultivation areas are differentiated. Future studies should clarify the area of rice field needed to support the home ranges and habitat requirements of small-clawed otters so that asynchronous farming areas may be systematically designated in the rice field landscape.

Acknowledgments: We thank Mahfud Huda, Ferdi Andeska, and other students at Andalas University for assistance with data collection in field surveys and anonymous reviewers for providing valuable comments on early drafts of this manuscript. We also thank the rice farmers for granting permission to conduct our field surveys in their rice fields and providing valuable local knowledge on small-clawed otters. The first author received a RISTEKDIKTI scholarship during a doctoral study at Kanazawa University. A portion of this research was funded by a Rufford Small Grant (No. 17544-2).

\section{References}

Aadrean, Novarino, W. and Jabang. 2011. A record of small-clawed otters (Aonyx cinereus) foraging on an invasive pest species, golden-apple snails (Pomacea canaliculata) in a West Sumatra rice field. IUCN Otter Specialist Group Bulletin 28: 34-38.

Aadrean, Salmah, S., Salsabila, A., Rizaldi and Janra, M. N. 2010. Tracks and other signs of otters in rice fields in Padang Pariaman, West Sumatra: a preliminary study. IUCN Otter Specialist Group Bulletin 27: 6-11.

Aadrean and Usio, N. 2017. Small-clawed otters (Aonyx cinereus) in Indonesian rice fields: latrine site characteristics and visitation frequency. Ecological Research 32: 899-908. DOI: 10.1007/ s11284-017-1496-6.

Abdul-Patah, P., Nur-Syuhada, N. and Md-Nor, S. 2014. Habitat and food resources of otters (Mustelidae) in Peninsular Malaysia. AIP Conference Proceedings 1614: 693-699. DOI: 10.1063/1.4895286.

Almeida, D., Barrientos, R., Merino-Aguirre, R. and Angeler, D. G. 2012. The role of prey abundance and flow regulation in the marking behaviour of Eurasian otters in a Mediterranean catchment. Animal Behaviour 84: 1475-1482. DOI: 10.1016/j.anbehav. 2012.09.020.

Amano, T., Kusumoto, Y., Tokuoka, Y., Yamada, S., Kim, E.-Y. and Yamamoto, S. 2008. Spatial and temporal variations in the use of rice-paddy dominated landscapes by birds in Japan. Biological Conservation 141: 1704-1716. DOI: 10.1016/j.biocon.2008.04.012.

Barocas, A., Golden, H. N., Harrington, M. W., McDonald, D. B. and Ben-David, M. 2016. Coastal latrine sites as social information hubs and drivers of river otter fission-fusion dynamics. Animal Behaviour 120: 103-114. DOI: 10.1016/j.anbehav.2016.07.016.

Bartoń, K. 2016. MuMIn: Multi-Model Inference, R Package version 1.15.6. Available at https://CRAN.R-project.org/package=MuMIn (Accessed 15 March 2018).

Bates, D., Mächler, M., Bolker, B. and Walker, S. 2015. Fitting linear mixed-effects models using lme4. Journal of Statistical Software 67: 1-48. DOI: 10.18637/jss.v067.i01.

Benton, T. G., Vickery, J. A. and Wilson, J. D. 2003. Farmland biodiversity: is habitat heterogeneity the key? Trends in Ecology \& Evolution 18: 182-188. DOI: 10.1016/S0169-5347(03)00011-9.

Collins, S. J. and Fahrig, L. 2017. Responses of anurans to composition and configuration of agricultural landscapes. Agriculture, Ecosystems \& Environment 239: 399-409. DOI: 10.1016/j.agee. 2016.12.038.

Crowley, S., Johnson, C. J. and Hodder, D. 2012. Spatial and behavioral scales of habitat selection and activity by river otters at latrine sites. Journal of Mammalogy 93: 170-182. DOI: 10.1644/ 10-MAMM-A-362.1.

Fahrig, L., Baudry, J., Brotons, L., Burel, F. G., Crist, T. O., Fuller, R. J., Sirami, C., Siriwardena, G. M. and Martin, J. L. 2011 Functional landscape heterogeneity and animal biodiversity in agricultural landscapes. Ecology Letters 14: 101-112. DOI: 10.1111/ j.1461-0248.2010.01559.x.

Foster-Turley, P. A. 1992. Conservation aspects of the ecology of Asian small-clawed and smooth otters on the Malay Peninsulas. IUCN Otter Specialist Group Bulletin 7: 26-29.

Fox, J. and Monette, G. 1992. Generalized collinearity diagnostics. Journal of the American Statistical Association 87: 178-183. DOI: 10.1080/01621459.1992.10475190.

Gonzalez, J. B. 2010. Distribution, Exploitation and Trade Dynamics of Asian Small-Clawed Otter (Amblonyx cinereus) Illiger 1815 in Mainland Palawan, Philippines. Bachelor Thesis, Western Philippines University, Palawan, Philippines, 47 pp.

Holt, J. and Chancellor, T. C. B. 1997. A model of plant virus disease epidemics in asynchronously-planted cropping systems. Plant Pathology 46: 490-501.

Hong, S., Gim, J., Kim, H. G., Cowan, P. E. and Joo, G. 2019. A molecular approach to identifying the relationship between 
resource use and availability in Eurasian otters (Lutra lutra). Canadian Journal of Zoology 97: 797-804. DOI: 10.1139/cjz2018-0289.

Hutchings, M. R. and White, P. C. 2000. Mustelid scent-marking in managed ecosystems: implications for population management. Mammal Review 30: 157-169.

International Rice Research Institute. 2007. Rice Production Course. Available at http://www.knowledgebank.irri.org/ericeproduction/ (Accessed 20 March 2017).

Kanchanasaka, B. and Duplaix, N. 2011. Food habits of the hairynosed otter (Lutra sumatrana) and the small-clawed otter (Aonyx cinereus) in Pru Toa Daeng Peat Swamp Forest, southern Thailand. IUCN Otter Specialist Group Bulletin 28: 139-149.

Kruuk, H. 1992. Scent marking by otters (Lutra lutra): signaling the use of resources. Behavioral Ecology 3: 133-140.

Kruuk, H. 2006. Otters: Ecology, Behaviour and Conservation. Oxford University Press, New York, 265 pp.

Kruuk, H., Kanchanasaka, B., O’Sullivan, S. and Wanghongsa, S. 1994. Niche separation in three sympatric otters Lutra perspicillata, $L$. lutra and Aonyx cinerea in Huai Kha Khaeng, Thailand. Biological Conservation 69: 115-120. DOI: 10.1016/0006-3207(94)90334-4.

Macdonald, S. M. and Mason, C. F. 1987. Seasonal marking in an otter population. Acta Theriologica 32: 449-461.

Monck-Whipp, L., Martin, A. E., Francis, C. M. and Fahrig, L. 2018. Farmland heterogeneity benefits bats in agricultural landscapes. Agriculture, Ecosystems \& Environment 253: 131-139. DOI: 10.1016/j.agee.2017.11.001.

Nakagawa, S. and Schielzeth, H. 2013. A general and simple method for obtaining $\mathrm{R}^{2}$ from generalized linear mixed-effects models. Methods in Ecology and Evolution 4: 133-142. DOI: 10.1111/ j.2041-210x.2012.00261.x.

Olson, Z. H., Serfass, T. L. and Rhodes, O. E. 2008. Seasonal variation in latrine site visitation and scent marking by nearctic river otters (Lontra canadensis). IUCN Otter Specialist Group Bulletin 25: 108-120.

Perinchery, A., Jathanna, D. and Kumar, A. 2011. Factors determining occupancy and habitat use by Asian small-clawed otters in the Western Ghats, India. Journal of Mammalogy 92: 796-802. DOI: 10.1644/10-MAMM-A-323.1.

Prenda, J., López-Nieves, P. and Bravo, R. 2001. Conservation of otter (Lutra lutra) in a Mediterranean area: the importance of habitat quality and temporal variation in water availability. Aquatic Conservation: Marine and Freshwater Ecosystems 11: 343-355. DOI: 10.1002/aqc.454.

Raha, A. and Hussain, S. A. 2016. Factors affecting habitat selection by three sympatric otter species in the southern Western Ghats, India. Acta Ecologica Sinica 36: 45-49. DOI: 10.1016/j.chnaes. 2015.12.002.

R Core Team. 2018. R: A Language and Environment for Statistical
Computing. R Foundation for Statistical Computing, Vienna, Austria. Available at http://www.r-project.org/ (Accessed 15 March 2018).

Ruiz-Olmo, J., Jiménez, J. and Chacón, W. 2007. The importance of ponds for the otter (Lutra lutra) during drought periods in Mediterranean ecosystems: A case study in Bergantes River. Mammalia 71: 16-24. DOI: 10.1515/MAMM.2007.003.

Settle, W. H., Ariawan, H., Astuti, E. T., Cahyana, W., Hakim, A. L., Hindayana, D. and Lestari, A. S. 1996. Managing tropical rice pests through conservation of generalist natural enemies and alternative prey. Ecology 77: 1975-1988. DOI: 10.2307/2265694.

Stevens, S. S. and Serfass, T. L. 2008. Visitation patterns and behavior of Nearctic river otters (Lontra canadensis) at latrines. Northeastern Naturalist 15: 1-12.

Sudarmaji, Singleton, G. R., Brown, P. R., Jacob, J. and Herawati, N. 2010. Rodent impacts in lowland irrigated intensive rice systems in West Java, Indonesia. In (Singleton, G., Belmain, S., Brown, P. and Hardy, B., eds.) Rodent Outbreaks: Ecology and Impacts, pp. 115-128. International Rice Research Institute, Los Baños (Philippines).

Usio, N. 2014. Environmentally friendly farming in Japan: introduction. In (Usio, N. and Miyashita, T., eds.) Social-Ecological Restoration in Paddy-Dominated Landscapes, pp. 69-86. Springer Japan, Tokyo.

Usio, N., Nakagawa, M., Aoki, T., Higuchi, S., Kadono, Y., Akasaka, M. and Takamura, N. 2017. Effects of land use on trophic states and multi-taxonomic diversity in Japanese farm ponds. Agriculture, Ecosystems \& Environment 247: 205-215. DOI: 10.1016/j. agee.2017.06.043.

Vasseur, C., Joannon, A., Aviron, S., Burel, F., Meynard, J. M. and Baudry, J. 2013. The cropping systems mosaic: How does the hidden heterogeneity of agricultural landscapes drive arthropod populations? Agriculture, Ecosystems \& Environment 166: 3-14. DOI: 10.1016/j.agee.2012.08.013.

Zhao, Z. H., Reddy, G. V. P., Hui, C. and Li, B. L. 2016. Approaches and mechanisms for ecologically based pest management across multiple scales. Agriculture, Ecosystems \& Environment 230: 199-209. DOI: 10.1016/j.agee.2016.06.010.

Zuur, A. F., Ieno, E. N. and Elphick, C. S. 2010. A protocol for data exploration to avoid common statistical problems. Methods in Ecology and Evolution 1: 3-14. DOI: 10.1111/j.2041-210X. 2009.00001.x.

Zuur, A. F., Ieno, E. N., Walker, N., Saveliev, A. A. and Smith, G. M. 2009. Mixed Effects Models and Extensions in Ecology with R. Springer, New York, 574 pp.

Received 8 April 2019. Accepted 3 December 2019. Published online 6 April 2020. Editor was Hayato Iijima. 